\title{
Installation of a Solar Refrigerator in South Africa
}

\author{
Daniel K. Jones ${ }^{1}$, Joshua Hill ${ }^{2}$, Oral LaFleur ${ }^{2}$, and Matthew Govindsanny ${ }^{3}$ \\ ${ }^{1}$ Department of Industrial and Engineering Technology, Central Michigan University, \\ Mt. Pleasant, MI, USA \\ ${ }^{2}$ School of Technology, Texas Southern University, \\ Houston, TX, USA \\ ${ }^{3}$ Department of Electrical Engineering, Eastern Cape Technikon, \\ Butterworth, South Africa
}

\begin{abstract}
This paper describes a cross-cultural engineering project involving students in high school and college. The primary objective was to inspire under-represented students to study engineering by hands-on experiences with electro-mechanical equipment. Another objective was to give students and faculty from the United States the opportunity to interact with colleagues in South Africa. This was accomplished by installing a solar-powered refrigerator in a remote South African village that did not have access to electric power. Students participated in all aspects of the project. After successful start-up of the refrigerator in a home, faculty at a South African university agreed to maintain the refrigerator and monitor its ongoing performance.
\end{abstract}

\section{Background}

The Renewable Energy and Environmental Protection (REEP) academy is an annual summer program held at Texas Southern University (TSU). ${ }^{1}$ The mission of REEP is to expose inner-city students to technology and to motivate them to pursue careers in math, science, technology, and engineering. Over 50 high school students gathered at TSU during summer 2000, with college students serving as mentors. ${ }^{2}$

This paper discusses one of the projects of REEP, the installation of a new solar refrigerator in South Africa. This was the result of collaboration between:

1. The environmental engineering technology program at TSU,

2. The mechanical engineering technology program at Central Michigan University,

3. The electrical engineering program at Eastern Cape Technikon in South Africa,

4. Solus, a company that developed the solar refrigerator, League City, Texas, and

5. National Aeronautics and Space Administration (NASA), Lyndon B. Johnson Space Center, Houston, Texas. 
During the REEP summer academy, faculty members from across the United States volunteered to provide hands-on instructional workshops and tours to local industries. All students gained a working knowledge of photovoltaic power production and solar panel assembly in special workshops. ${ }^{3}$

\section{System Design}

Because energy collected from the sun is not constant, most solar-powered devices have batteries to store electric energy and provide a consistent power source. When the sun is shining, batteries are charged to store energy. The energy is then available at night and during cloudy weather.

A unique solar refrigerator, developed by a company in the United States, ${ }^{4}$ was designed to operate without a battery. Instead of storing electric energy, this battery-free solar refrigerator stored thermal energy in the coolant. Photovoltaic panels converted solar power into electricity, which directly powered the refrigerator. When the sun was not shining, the refrigerator relied on insulation and the thermal capacity of the coolant to maintain cool temperatures.

The rationale of this design was that a battery-free system would be lighter and less expensive. Also, in areas that do not have electricity, batteries are subject to theft. A disadvantage of this configuration is that a lack of sun results in less refrigeration. A modified coolant (R-134a) was used to provide higher thermal capacity, keeping the refrigerator cold while the sun was not shining. A disadvantage of this coolant was that its viscosity increased dramatically near freezing, and so it could not maintain freezing temperatures in the cooling chamber. Because temperatures in the refrigerator would not generally reach freezing, the system was intended to provide cooling of food and medicine.

The weight of the refrigerator was $712 \mathrm{~N}$, and its exterior dimensions were $94 \mathrm{~cm}$ wide, $70 \mathrm{~cm}$ deep, and $88 \mathrm{~cm}$ high. With $11 \mathrm{~cm}$ of polyurethane insulation, the interior volume was 1130 liters. Cool temperatures could be maintained in this chamber by consuming 65 watts of power for as little as 2.5 hours per day. ${ }^{4}$ Two solar panels, providing 90 watts of power, were sufficient for this demand.

This solar refrigerator was tested at an independent laboratory, and it operated successfully for a period of one year. Testing was conducted at the NASA Lyndon B. Johnson Space Center, in Houston, Texas, which is at $30^{\circ}$ latitude in the Northern hemisphere. The installation site in South Africa was at $30^{\circ}$ latitude in the Southern hemisphere. Both regions experience similar weather conditions, at opposite times of the year.

\section{Installation}

Delegates from the U.S. have traveled to isolated villages in South Africa annually for the past five years. ${ }^{5}$ In July 2000, a subgroup of the REEP 2000 summer academy traveled to South Africa to install a solar refrigerator. This delegation consisted of five high school students, five 
college students, two faculty members, a culture/language specialist, and two media representatives.

The installation site was the small rural village of Centani in the Eastern Cape Province. Centani had no access to electrical utilities because it was not on the power grid. This site was selected, in part, because of its close proximity to Eastern Cape Technikon (ECT), a university with faculty who agreed to periodically monitor the ongoing performance of the refrigerator.

Before the delegation traveled to South Africa, the refrigerator was shipped to ECT. This ensured clearance through customs and timely delivery of the system. The U.S. delegation visited ECT faculty and students, who had built mounting brackets for the solar panels. The delegation then transported the refrigerator, solar panels, and mounting brackets to Centani. Although students and faculty at ECT spoke English fluently, residents of the rural village spoke little English, and so our language specialist translated verbal communication. Most of the installation activities were communicated nonverbally.

After inspecting the site, the crew decided to mount the solar panels on the roof of the home that would house the refrigerator. The two solar panels, each $60 \mathrm{~cm}$ by $180 \mathrm{~cm}$, were very light weight, but the mounting brackets, constructed from welded metal, were too heavy for the roof. And so the welded metal frame was discarded, and the panels were secured to the roof with a wooden structure that was constructed on site. After testing of the solar panels, wires were pulled through the walls of the home to the refrigerator, which was placed in a back room. Fortunately, it was a very sunny day; as soon as the wires were connected, the refrigerator worked well.

\section{Conclusion}

This project provided a positive technical and cross-cultural educational experience for all students involved. Faculty served as mentors to undergraduate students, who in turn served as mentors to the high school students. Students from the U.S. were very enthusiastic about their interaction with South African colleagues, and they expressed an increased interest in technology.

The overall impact of the entire trip was extremely powerful, changing the lives of many delegates. The project discussed in this paper was accomplished during two days of a ten-day trip, and so this project was only part of the entire experience. The specific impact of the solar refrigerator installation, in terms of the students' reactions, was difficult to delineate from the rest of the trip.

The cultural aspects of the installation impacted individual members of the U.S. delegation differently. The reaction of the U.S. students to the community without electricity was mixed. Although verbal communication was very limited due to the language barrier, students appeared to share common bonds with the villagers. The U.S. students enjoyed the opportunity to help the South Africans. Upon departure, the villagers appeared to be grateful for the efforts of the U.S. delegation. 
Successful installation of this battery-free solar refrigerator has provided a test site to evaluate its feasibility throughout the year. From a technical perspective, variable factors include the weather conditions and the orientation of the sun throughout the year. From a cultural perspective, the acceptance and use of the refrigerator by the villagers remain open questions.

Ongoing collaboration between faculty members in the United States and South Africa will determine the long-term technical and sociological success of the solar refrigerator. Authors have a linkage grant through USAID/UNCF (U.S. Aid for International Development/United Negro College Fund.) This may lead to more widespread use in the future.

\section{Acknowledgement}

The authors thank the financial supporters of REEP. Underwriters included Browning-Ferris Industries, EPRI, Honeywell Foundation, Houston Newspages, Houston Endowment Inc., National Renewable Energy Laboratory/US DOE, Reliant Energy Foundation, Reliant HL\&P, State Energy Conservation Office (SECO), The Port of Houston, and TXU Electric \& Gas. Sponsoring Organizations included Allstate Insurance, Guaranty Federal Bank, Montgomery Watson, Rapoport Foundation, Waco Foundation, Wells Fargo Online, and Watt Watchers of Texas. The authors also appreciate the critical work of Rashaan Arscott and Pearl Selane. The authors thank all the citizens of South Africa that we encountered during our journey; their hospitality was overwhelming.

\section{References}

1. http://technology.tsu.edu/REEP/Program.HTM

2. REEP 2000 Millenium Program, School of Technology, Texas Southern University, Houston, Texas.

3. Richard Komp, Ph.D., SunWatt Corp., Jonesport, Maine.

4. Solus Battery Free Solar Refrigerator User Guide, published by Solus, League City, Texas.

5. M.N. Guillory, "From Darkness into Light: REEP Brightens South Africa," Houston Defender, September 5-11, 1999, pp. 41-4. 


\section{DANIEL K. JONES}

Daniel Jones, Ph.D., P.E., is an Assistant Professor in the Industrial and Engineering Technology Department at Central Michigan University. He is a registered professional engineer and teaches a variety of courses in mechanical engineering technology. Dr. Jones participated in the REEP 2000 summer academy, traveled with the delegation to South Africa, and coordinated the mechanical aspects of the installation.

\section{JOSHUA HILL}

Joshua Hill, Ed.D., is a Professor and Associate Dean of the School of Technology at Texas Southern University. Dr. Hill is the founder, director, and principal fundraiser for REEP. He has been traveling to South Africa for many years, establishing the networks required for this project. Dr. Hill coordinates the REEP summer academies and recruits students, staff, and faculty from around the world.

\section{ORAL LAFLEUR}

Oral LaFleur is a research associate in the renewable energy laboratories in the School of Technology at Texas Southern University. He is a REEP staff member and Technical/Program Development Coordinator for the REEP 2000 summer academy. Mr. LaFleur has traveled with the REEP delegation to South Africa for many years, and he provided expertise on the electrical systems of the solar refrigerator.

\section{MATTHEW GOVINDSANNY}

Matthew Govindsanny is currently a professor of electrical engineering at Eastern Cape Technikon in Butterworth, Republic of South Africa. He provided early preparation for the installation, critical technical assistance, and access to the laboratories, shops, and equipment during the installation. Professor Govindsanny is monitoring the ongoing performance of the solar refrigerator. 